\title{
References
}

\section{ARABIC REFERENCES}

Abd al-Jabbar, Qadi (1965), al-Mughn̄̄ fì 'Ajāi'b al-Tawhīd wa'l-'Adl, edited by M. Ali Najjar and Halim Najjar, Cairo, al-Mu'assash alMisriyah al- Ammah li'l-Talif.

Abu Dawud (n.d.), Sunan Abi Dawud, Beirut, al-Maktabah al-Asriyah, Vol. 3

Abu-Ubayd (1986), Kitāb al-Amwāl, Beirut, Dar al-Kutub al-Ilmiyah.

Abu-Yusuf (1392), Kitāb al-Kharäj, Cairo, Dar al-Matba'ah al-Salafiyah. Ahmad, Abd al-Rahman Yousri (2001), Tațawwur al-Fikr al-Iqtișādī, Alexandria, al-Dar al-Jamicyah.

al-Aqțash, Abd al-Majid Muhammad (1985), Abu Dharr al-Ghifärī wa Arä'uhü fi'l-Siyāsah wa'l-Iqtișād [Abu Dharr and His Views on Political and Economic Issues], Amman, Maktabah al-Aqsa.

al-Asadi, Muhammad b. Muhammad b. Khalil (1967), al-Taysìr wa'lI'tibār wa'l-Tahrīr wa'l-Ikhtibār fì mā yajib min Husn al-Tadbīr wa'lTașarruf wa'l-Ikhtiyār, edited by Abd al-Qadir al-Tulaymat, Cairo, Dar al-Fikr al-Arabi.

al-Asfahani, al-Husayn al-Raghib (1985), al-Dharīah ilā Makārim al-Sharīah, Cairo, Dar al-Sahwah; al-Mansurah, Dar al-Wafa.

Awwad, Sarkis (1943), 'al-Hisbah fī Khazānat al-Kutub al-Arabīyah' (works on al-hisbah in Arabian libraries), Majallat al-Majma' al-' Ilmī al-`Arabī, 18 (1-2), 417-28.

al-Baji, Abu'l-Walid (1332 A.H.), al-Muntaqā Sharh al-Muwatțāa, Beirut, Dar al-Kitāb al-Arabi.

al-Baladhuri, Ahmad (1983), Futūh al-Buldān, edited by Muhammad Ridwan, Beirut, Dar al-Kutub al-Ilmiyah.

al-Bayhaqi, Abu Bakr Ahmad (1999), al-Sunan al-Kubrā, Beirut, Dar alKutub al-Ilmiyah, Vol. 5.

al-Burno, Muhammad Sidqi (1400 A.H.), 'Umar b. 'Abd al-'Aziz wa Tașhīhātuhu li-Bayt al-Mäl [Umar b. Abd al-Aziz and his Reforms of the Public Treasury], Riyadh, Jāmic at al-Imām, Ph.D. Thesis.

al-Dimashqi, Abu'l-Fadl Ja'far (1977), al-Ishārah ilā Mahāsin al-Tijārah, edited by al-Shorabji, Cairo, Maktabah al-Kulliyat al-Azhariyah. 
Dunya, Shawqi Ahmad (1998), Silsilah A'lām al-Iqtișād al-Islāmī, Book III, Cairo, Markaz Salih Kamil li'l-Iqtisad al-Islami, pp. 19-63, 121-73. al-Farra, Abu Yala (1966), al-Ahkēm al-Sulțānīyah, Egypt, Al-Babi alHalabi.

al-Ghazali, Abu Hamid (n.d.[a]), 'Ihyā' 'Ulūm al-Dìn, Beirut, Dar alNadwah.

al-Ghazali, Abu Hamid (n.d.[b]), al-Mustașfā min Ușūl al-Fiqh, Beirut, Dar Sadir.

al-Ghazali, Abu Hamid (n.d.[c]), Shifā al-Ghalīl, Baghdad, al-Irshad Press. al-Ghazali, Abu Hamid (1964), al-Tibr al-Masbūk fi Nașịhat al-Mulūk, translated and edited by F.R. Bagley as the Book of Counsel for Kings, Oxford, Oxford University Press.

al-Ghazali, Abu Hamid (1964), Mīzān al-'Amal, edited by Sulayman Dunya, Cairo, Dar al-Ma'arif.

al-Hashimi, Muhammad Yahya (1937), 'Naẓarīyat al-Iqtișād 'ind al-Bīrūni’' [Economic Views of al-Biruni], Majallat al-Majma' al-'Ilmī al-'Arabī, (Damascus), 15 (11-12), 456-65.

Ibn Abd al-Salam, al-Izz (1992), Qawā'id al-Ahkām, Damascus, Dar al-Taba'ah.

Ibn Abi al-Dunya (1990), Ișlăh al-Māl [Betterment of Wealth], edited and published by Mustafa Muflih al-Qudah, al-Mansurah, Dar al-Wafa.

Ibn Abi al-Rabīic (1978), Sulūk al-Mālik fì Tadbīr al-Mamālik, Beirut, Turath 'Uwaydat.

Ibn al Athīr (1989), Usd al-Ghābah, Bierut, Dar al-Fikr.

Ibn al-Azraq (1977), Badā' 'ं $i^{c}$ al-Silk fì Tabāa' $i^{\prime}$ al-Mulk, Baghdad, Wazarat al- I'lam.

Ibn Battutah, (1968), Tuhfat al-Nuzzā̄r fì Gharā’ib al-Amșār wa 'Ajā’ib al-Asfār, Beirut, Dar al-Turath.

Ibn al-Hajj (1972), al-Madkhal ilā Tanmiyat al-A`māl bi Tahsin al-Nīyāt, Beirut, Dar al-Kitab al-Arabi.

Ibn Hanbal (n.d.), Musnad, Beirut, al-Maktab al-Islami.

Ibn Hazm (1347 A.H.), al-Muhallā, Egypt, Matba'ah al-Nahdah.

Ibn al-Humam, (n.d.), Sharh Fat'h al-Qadīr, Cairo, al-Maktabah alTijariyah al-Kubra.

Ibn Ja'far, Qudamah (1981), Kitāb al-Kharāj wa Sināáat al-Kitābah, Baghdad, Dar al-Rashid.

Ibn Jamā̄ah (1987), Tahrīr al-Ahkēm fì Tadbìr Ahl al-Islām, edited by Fu'ad Ahmad, Qatar, Presidency of the Shar'iyah Court and Religious Affairs, 2nd edn.

Ibn al-Jawzi, Abd al-Rahman (1962), Dhamm al-Hawā, edited by Abd alWahid, Mustafa, n.p.

Ibn al-Jawzi, Abd al-Rahman (n.d.), al-Shifä’ fì Mawā'iz al-Mulūk wa'l- 
Khulafä', edited by Fuad Abd al-Mun'im Ahmad, Makkah al-Mukarramah, al-Maktabah al-Tijariyah.

Ibn Khaldun (n.d.), Muqaddimah, Beirut, Dar al-Fikr.

Ibn al-Qayyim (1982), Zād al-Macād, edited by Shu'ayb al-Arnaut, Beirut. Ibn al-Qayyim (1955), I'läm al-Muwaqqi ìn, Cairo, Maktabah al-Sa'adah. Ibn al-Qayyim (1953), al-Ṭruq al-Hukmīyah, Cairo, Matba'ah al-Sunnah al-Muhammadiyah.

Ibn al-Qayyim (1375 A.H.), Madārij al-Sālikīn, Cairo, al-Muhammadiyah.

Ibn Qudamah (1972), al-Mughnī, Beirut, Dar al-Kitab al-Arabi.

Ibn Rushd (1988), Bidāyat al-Mujtahid, Beirut, Dar al-Ma'rifah.

Ibn Taymiyah (1986) Mukhtașar al-Fatāwā al-Miṣrīyah, edited by Muhammad al-Ba'li, Dammam, Dar Ibn al-Qayyim.

Ibn Taymiyah (1976), al-Hisbah fi'l-Islām, Cairo, Dar al-Sha'b. English translation by Holland, Muhtar (1982), Public Duties in Islam: The Institution of the Hisbah, Leicester, The Islamic Foundation.

Ibn Taymiyah (1971), al-Siyāsah al-Shar'̄yah, Cairo, Dar al-Sha‘b. English translation by Farrukh, Omar (1966), Ibn Taimiya on Public and Private Laws in Islam, Beirut, Khayats.

Ibn Taymiyah (1964), al-Masä̉il al-Mārdīnìyah, Damascus, al-Maktab al-Islami.

Ibn Taymiyah (1963), Majmū̄ Fatāwā Shaykh al-Islām Ahmad Ibn Taymiyah, edited by al-Najdi, Abd al-Rahman b. Muhammad, Al-Riyad, Matabic al-Riyad.

Ibn al-Ukhuwwah (1938), Ma'ālim al-Qurbah fĩ Ahkām al-Hisbah, edited and translated by Ruben Levy, with Arabic text, London, Cambridge University Press.

al-Jāḥiz, 'Amr b. Baḥr (1966), Kitāb al-Tabașsur bill-Tijārah, edited by Abdul-Wahhab, Hasan Hasani, Tunis, Dar al-Kitāb al-Jadid.

al-Juwayni, Abd al-Malik (1400 H.), al-Burhān fì Ușül al-Fiqh, Cairo, Dar al-Ansar, 2nd ed., two parts in one volume.

al-Juwayni, Abd al-Malik (1981) al-Ghayāthī, edited by Abd al-Azim al-Deib, Cairo: Matba'ah Nahdah Misr.

al-Juwayni, Abd al-Malik (1950), al-Irshād ilā Qawātic al-Adillah fi Ușūl al-I tiqad edited by Musa, M. Yusuf and Abd al-Hamid, Ali Abd al-Mun'im, Cairo, Maktaba al-Khanji.

Kahf, Monzer (1995), al-Nușuṣ al-Iqtișādīyah min al-Qur'an wa'l-Sunnah [Economic Texts from the Qur'an and Sunnah], Jeddah, Markaz alNashr al-Ilmi, KAAU.

al-Kasani, Ala al-Din (n.d.), Badā' '` $i^{\complement} a l-S a n a^{\prime} i^{\prime}$, Cairo, Shirkat al-Matbu'at, al-Ilmiyah.

Khallaf, Abd al-Wahhab (1954), Mașādir al-Tashri` al-Islāmī fì mā lā Nașs 
fîhi, Cairo, Ma'had al-Dirasat al-'Arabiyah al-'Alamiyah.

al-Kinani, Yahya b. Umar (1975), Ahkām al-Sūq, edited by Abd al-Wahhab, Hasan Hasni, Tunis, al-Shirkah al-Tunisiyah li'l-Tawzi'.

al-Maghribi, Abu'l-Qasim Husayn b. Ali (n.d.), 'al-Siyāsah' in Majmū fi'l-Siyāsah, edited by Fu'ad Abd al-Mun'im Ahmad, Alexandria: Mu'assasah Shabab al-Jamicah, pp. 35-60.

al-Maqdisi, Ibn Qudamah, Abd al-Rahman (1972), al-Sharh al-Kabīr, printed at the foot of al-Mughnī by Ibn Qudamah, Beirut, Dar al-Kitāb al-Arabi, 12 Vols.

al-Maqrizi, Muhammad Ali (1997), Kitāb Durar al-Sulūk fì Siyāsat al-Mulük, al-Riyad, Dar al-Watan.

al-Maqrizi, Muhammad Ali (1983), Nașīhat al-Mulūk, edited by Khidr Muhammad Khidr, al-Sifah (Kuwait), Maktabat al-Falah.

al-Maqrizi, Muhammad Ali (1981), Tas'hīl al-Nazar wa Ta'jül al-Zafar, Beirut, Dar al-Nahdah al-Arabiyah.

al-Maqrizi, Muhammad Ali (1956), Kitāb al-Sulūk, Cairo, Lajnah al-Talif wa'l-Tarjamah, Vol. 2.

al-Maqrizi, Muhammad Ali (1940), Ighāthat al-Ummah bi Kashf al-Ghummah, Cairo, Lajnah al-Talif wa'l-Tarjamah.

al-Mawardi, Ali (1981), Tas'hil al-Nazar wa Ta 'jil al-Zafar, Beirut, Dar al-Nahdah al-Arabiyyah.

al-Mawardi, Ali (1979), Adab al- Dunyā wa'l-Dīn, Beirut, Dar Ihyā̄' alTurath al-Arabi.

al-Mawardi, Ali (1973), al-Aḥkām al-Sulțānīyah, Egypt, al-Babi al-Halabi. al-Mawardi, Ali (1929), Adab al-Wazir, Egypt, Maktabah al-Khanji.

al-Mawardi, Ali (n.d.), al-Tuhfat al-Mulūkīyah fi'l-Ādāb al-Siyāsīyah, edited by Fu'ad Abd al-Mun'im. Alexandria, Mu'assasah Shabab al-Jamicah.

al-Misri, Rafic Yunus (1999), Fi'l-Fikr al-Iqtișādī al-Islāmī:Qira'āt fi'lTurath [On Islamic Economic Thought: Readings in the Heritage], Jeddah, Markaz al-Nashr al-Ilmi, King Abdulaziz University.

al-Misri, Rafic Yunus (1981), al-Isläm wa'l-Nuqūd [Islam and Money], Jeddah, International Center for Research in Islamic Economics, 2nd edn (1990).

Miskawayh (1964), Risālah fì Māhīyat al- ${ }^{`} A d l$, edited and translated by M.S. Khan, Leiden, Brill.

Miskawayh (n.d.), Tahdhīb al-Akhlāq, Cairo, al-Matba' ${ }^{a}$ ah al-Misriyah. al-Mawsili, Muhammad b. Muhammad b. Abd al-Karim (1416), Kitāb Husn al-Sulūk al-Hāfiz Dawlat al-Mulük, al-Riyad, Dar al-Watan.

al-Mubarak, Muhammad (1973), Arrä' Ibn Taymīyah fi'l-Dawlah, Beirut, Dar al-Fikr.

Muslim (n.d.), Șahīh, Cairo, Maktabah M. Ali Sabih, Vol. 5. 
Nash'at, Muhammad Ali (1944), al-Fikr al-Iqtișādī fì Muqaddimat Ibn Khaldūn [Economic Thought in the Prolegomena of Ibn Khaldun], Cairo, Dar al-Kutub al-Misriyah.

al-Nawawi, Muhi al-Din (n.d.), al-Majmūe, edited by M.N. al-Mutici, Jeddah, Maktabat al-Irshad.

Nuqli, Isam Abbas (1998), Thabt: Bibliography (contemporary Arabic works on history of Islamic economic thought), Jeddah, King Abdulaziz University.

Qala'ji, Muhammad Rawwas (1408 A.H.), 'al-Fikr al-Iqtișād̄̄ 'ind 'Umar bin al-Khațāā' [Economic Thinking of Umar bin Khattab], Majallah Markaz Buhūth al-Sunnah, 3, 187-207.

al-Qurashi, Yahya b. Adam (1987), Kitāb al-Kharāj, Cairo and Beirut, Dar al- Shuruq.

al-Raḍī, al-Sharif (n.d.), Nahj al-Balāghah min Kalām 'Alī ibn Abī Taālib, Cairo, Al-Istiqamah Press.

al-Rayes, Dia al-Din (1957), al-Kharāj fì al-Dawlah al-Islāmīyah, Cairo, Maktabah Nahdah Misr.

al-Rāzi, Fakhr al-Din (1938), al-Tafsīr al-Kabīr, Cairo, al-Matba'ah alBahiyah.

Salih, Muhammad Zaki (1933), 'al-Fikr al-Iqtiṣādī al-'Arabì fi'l-Qarn al-Khämis 'Ashar' [Arab Economic Thought in the Fifteenth Century], Majallat al-Qānūn Wa'l-Iqtișād, 3 (3), 15-360 and 3 (6), 755-809.

al-Șana'āni, Abd Al-Razzaq (1403 H.), Mușannaf Abd al-Razzāq, Beirut, al-Maktab al-Islāmi, Vol.8.

Sezgin, Fuat (1984), Muhādarāt fì Tarīkh al-'Ulūm al-'Arabīyah wa'lIslāmiyah, [Lectures on Arabic and Islamic Sciences], Frankfort, IGAIW. Shalbi, Mahmud (1974), Ishtirakīyatu 'Uthmān [Socialism of Uthman], Beirut, Dar al-Jil.

al-Shāțibi, Ibrahim (n.d.[a]), al-I tișām, Beirut, Dar al-Ma'rifah.

al-Shāțibi, Ibrahim (n.d.[b]), Al-Muwāfaqāt, Cairo, al-Maktabah alTijariyah.

al-Shaybani, Muhammad b. Hasan (1986), al-Iktisāb fi’l-Rizqal-Mustațāb, Beirut, Dar al-Kutub al-Ilmiyah.

al-Shayzari, Abd al-Rahman b. Nasr (1407 H.), al-Manhaj al-Maslūk fì Siyāsat al-Mulūk, edited by Ali Abd-Allah al-Musa, al-Zarqa (Jordan), Maktabat al-Manar.

al-Shayzari, Abd al-Rahman b. Nasr (n.d.), Nihāyat al-Rutbah fĩ Talab al-hisbah or Ahkām al-Hisbah, Beirut, Dar al-Thaqafah.

al-Shirazi, Ibrahim (1976), al-Muhadhdhab, Cairo, al-Babi al-Halabi.

al-Sindi, Nur al-Din, (1986), Hāshiyat al-Sindī 'alā al-Nisā' $\bar{\imath}$, edited by Abd al-Fattah Abu Ghuddah, Aleppo, Maktab al-Matbu'cat al-Islāmiyah, Vol. 7. 
al-Subki, Taj al-Din Abu Nasr 'Abd al-Wahhab (1978), Mu'id al-Ni'am wa Mubīd al-Niqam, edited by David W. Myhram, New York, AMS Press. Reprint of the 1908 edn, London, Luzac.

al-Subki, Taqi al-Din Ali b. Abd al-Kafi (n.d.), Fatāwā al-Subkī, Beirut, Dar al-Ma'rifah.

al-Sunnami, Muhammad b. Awad (1986), Nișāb al-Iḥtisāb, edited by Murayzan Sa id Murayzan Asiri, Makkah, Maktabat al-Talib al-Jami'i. al-Suyuți (1968), Husn al-Muhādarah fì Mulūk Miṣr wa'l-Qāhirah, Cairo, Dar Iḥyā' al-Kutub al-Arabiyah. Vol. 2.

al-Ṭarasusi, Ibrahim b. Ali (1992), Tuhfat al-Turk fì mā Yajib an yu'mal fi'l-Mulk, edited by Radwan al-Sayyid, Beirut, Dar al-Tali'ah.

al-Tirmidhi, Abu Isa (1976), al-Jāmic al-Sahīh, Egypt, Mustafa al-Babi al-Halabi.

al-Tusi, Nizam al-Mulk (1961), Siyasat Namah translated by Hubert Darke, London.

al-WaȘabi, Muhammad b. Abd al-Rahman (1982), al-Barakah fí fadl al$S a^{c}$ y wa'l-Harkah, Beirut, Dar al-Marifah.

al-Zayla 'i, Uthman (n.d.), Tab'inn al-Haqā'iq, Beirut, Dar al-Marifah.

Ziadeh, Nicola, (1963), al-Hisbah wa'l-Muhtasib fi'l Isläm, Beirut, Catholic Press.

\section{OTHER REFERENCES}

Abdul-Qadir (1941), 'The Social and Political Ideas of Ibn Khaldun', Indian Journal of Political Science, 3 (2), 898-907.

Abulafia, D. (1994), 'The Role of Trade in Muslim Christan Contact during the Middle Ages', in D.A. Agius and R. Hitchcok (eds), The Arab Influence in the Medieval Europe, Reading: Ithaca Press, pp. 1-24.

Aghnides, Nicolas P. (1916), Mohammedan Theories of Finance, New York: Columbia University Press.

Ali, Abdullah Yusuf (1975) (translation and commentary), The Holy Qur'an, Leicester: The Islamic Foundation.

Ali, Abid Ahmed (1979) (translation), Kitāb al-Kharāj by Abu-Yusuf, Lahore: Islamic Book Centres.

al-Djazairi, S.E. (2005), The Hidden Debt to Islamic Civilization, Oxford: Bayt al-Hikma Press.

Anawati, Georges C. (1974), 'Philosophy, Theology and Mysticism', in J. Schacht (ed.), The Legacy of Islam, Oxford: The Clarendon Press.

Aquinas, Thomas (1947), Summa Theologica, New York: Benziger Brothers, II: II Q77 and Q78). 
Artz, Frederick, B. (1953), The Mind of the Middle Ages C.E. 200-1500: A Historical Survey, New York: Aflred A. Knopf.

Asad, Muhammad (1980) (translation and explanation), The Message of the Qur'an, Gibralter: Dar al-Andalus.

Ashley, William J. (1893-1906), An Introduction to English Economic History and Theory, New York: G.P. Putnam and Sons, Vols 1 and 2.

Baeck, Louis (1994), The Mediterranean Tradition in Economic Thought, London and New York: Routledge.

Bates, Michael L. (1989), 'Crusade Coinage with Arabic Inscriptions, in Kenneth M. Satton (ed.), A History of the Crusades, Madison: University of Wisconsin Press, 6, 421-82.

Bell, J.F. (1967), A History of Economic Thought, New York: The Ronald Press Company, 2nd edn.

Bernardelli, H. (1961), 'The Origins of Modern Economic Theory', Economic Record, 37, 320-38.

Boulakia, Jean David C. (1971), 'Ibn Khaldun: A Fourteenth Century Economist', Journal of Political Economy, 79 (5), 1105-18.

Briffault, R. (1928), The Making of Humanity, London: George Allen and Unwin Ltd.

Briffault, R. (1919), The Making of Humanity, London: George Allen and Unwin Ltd.

Burnett, Charles (1994), 'The Translating Activity in Medieval Spain', in Salma Khadra Jayyusi (ed.), The Legacy of Muslim Spain, Leiden: E.J. Brill, pp. 1036-58.

Carra de Vaux, Baron (1931), 'Astronomy and Mathmetics, in T. Arnold and A. Guillaume (eds) The Legacy of Islam, Oxford: Oxford University Press, 1st edn, pp. 376-97.

Chapra, Mohammad Umer (2009), 'The Global Financial Crisis: Can Islamic Finance Help?', in Issues in the International Financial Crisis from an Islamic Perspective, prepared by Group of Researchers, Islamic Economic Research Center, Jeddah: King Abdulaziz University.

Chejne, Anwar (1980), 'The role of al-Andalus in the movement of ideas between Islam and the West', in Khalil Semaan (ed.), Islam and the West, Albany: State University of New York Press.

Cochrane, Louise (1994), Adelard of Bath, London: British Museum Press.

Cook, M.A. (1974), 'Economic Developments', in J. Schacht and C.E Bosworth (eds), The Legacy of Islam, Oxford: The Clarendon Press, 2nd edn.

Copleston, F.C. (1972), A History of Medieval Philosophy, New York: Harper and Row.

Crowther, Geoffrey (1967), An Outline of Money, London: Nelson. 
Dalton, Hugh (1966), Principles of Public Finance, London: Routledge \& Kegan Paul.

Daniel, Norman (1975), The Culture Barrier: Problems in the Exchange of Ideas, Edinburgh: Edinburgh University Press.

al-Dawani, Jalal al-Din (1839), Akhlāq-i Jaläli, translated by W.F.Thomas, London: Oriental Translation Fund of Great Britain and Ireland.

de Roover, Raymond (1976), Business Banking and Economic Thought, Chicago and London: The University of Chicago Press.

Durant, Will (1950), The Story of Civilization: The Age of Faith, New York: Simon \& Schuster, Vol. 4.

Ekelund (Jr.), Robert B. and Hebert, Robert F. (1983), A History of Economic Theory and Method, New York: McGraw-Hill.

Essid, Yassine (1995), A Critique of the Origins of Islamic Economic Thought, Leiden: E.J. Brill.

Essid, Yassine (1987), 'Islamic Economic Thought', in Lowry S. Todd (ed.), Pre-Classical Economic Thought, Boston: Kluwer Academic Publishers, pp. 77-102.

Fay, Charles (1956), Adam Smith and Scotland of His Day, Cambridge: Cambridge University Press.

Gabrieli, F. (1970), 'The Transmission of learning and Literary Influences to Western Europe', in P.M. Holt, A.K.S. Lambton and B. Lewis (eds), The Cambridge History of Islam, Cambridge: Cambridge University Press, Vol. 2, pp. 851-89.

Ghazanfar, S.M. (ed.) (2003), Medieval Islamic Economic Thought, London and New York: RoutledgeCurzon.

Ghazanfar, S.M. (1995), 'History of Economic Thought: The Schumpeterian Great Gap, The Lost Arab. Islamic Legacy and the Literature Gap', Journal of Islamic Studies, 6 (2), 234-53.

Ghazanfar, S.M. and Islahi, Abdul Azim (1998), Economic Thought of alGhazali, Jeddah, Scientific Publishing Centre, KAAU.

Ghazanfar, S.M. and Islahi, Abdul Azim (1990), 'Economic Thought of an Arab Scholastic: Abu Hamid Al-Ghazali', History of Political Economy, 22 (2), 381-403.

Goitein, S.D. (1967), A Mediterranean Society, Berkeley: University of California Press.

Gordon, Barry (1975), Economic Analysis before Adam Smith, New York: Barnes and Noble.

Gray, Alexander (1967), The Development of Economic Doctrine, London: Longmans.

Gregory, Paul A. and Robert C. Stuart (2004), Comparing Economic Systems in the Twenty-First Century, Mason: South-Western Cengage Learning, 7 th edn. 
Grice-Hutchinson, Marjorie (1978), Early Economic Thought in Spain, 1177-1740, London: George Allen \& Unwin.

Hamdani, Abbas (1994), 'An Islamic Background to the Voyages of Discovery', in Salma Khadra Jayyusi (ed.), The Legacy of Muslim Spain, Leiden: E.J. Brill, 273-306.

Hamidullah, Muhammad (1968), The Muslim Conduct of the State, Lahore: Sh. Muhammad Ashraf, 5th edn.

Harris, C.R.S. (1954), Duns Scotus, New York: Humanity Press.

Haskins, Charles H. (1927), The Renaissance of the Twelfth Century, Cambridge, MA: Harvard University Press.

Hayes, J.R. (ed.) (1983), The Genius of Arab Civilization: Source of Renaissance, 2nd edn, Cambridge MA: MIT Press.

Heaton, Herbert (1948), Economic History of Europe, New York: Harper.

Heckscher, Eli F. (1954), Mercantilism, translated by Mendal Shapiro, London: George Allen and Unwin.

Heffening, W. (1934), 'Tadbïr', in The Encyclopaedia of Islam, Old Edition, Leiden: E.J. Brill and London, Luzac and Co., Vol. 4, p. 595.

Hernandez, Miguel Cruz (1994), 'Islamic Thought in the Iberian Peninsula', in Salma Khadra Jayyusi (ed.), The Legacy of Muslim Spain, Leiden: E.J. Brill, pp. 777-803.

Hill, D.R. (1993), Islamic Science and Engineering, Edinburgh: Edinburgh University Press.

Hosseini, Hamid S. (2003), 'Contributions of Medieval Muslim Scholars to the History of Economics and their Impact: A Refutation of the Schumpeterian Great Gap', in Warren J. Samuels, Jeff E. Biddle and John B. Davis (eds), A Companion to the History of Economic Thought, Malden: and Oxford: Blackwell Publishing Ltd, pp. 28-45.

Hunter, M.H. and H.K. Allen (1940), Principles of Public Finance, New York: Harper and Brother.

IAFIE (2000), Islamic Economics Bulletin, Indian Association for Islamic Economics, 10, 6.

Ibn Khaldun (1967), Muqaddimah of Ibn Khaldun, (An Introduction to History), translated by F. Rosenthal, New York: Princeton University Press.

Iqbal, Sir Muhammad (2006), The Reconstruction of Religious Thought in Islam, New Delhi: Kitab Bhawan (reprint edn).

Islahi, Abdul Azim (2011), A Study of Muslim Economic Thinking in the 11th A.H./17th C.E. Century, Jeddah: Scientific Publishing Centre, King Abdulaziz University.

Islahi, Abdul Azim (2011), Islamic Economic Thinking in The 12th A.H./18th C.E. Century With Special Reference To Shah Wali-Allah 
Al-Dihlawi, Jeddah: Scientific Publishing Centre, King Abdulaziz University.

Islahi, Abdul Azim (2009), Muslim Economic Thinking and Institutions in the 10th A.H./16th C.E. Century, Jeddah: Scientific Publishing Centre, King Abdulaziz University.

Islahi, Abdul Azim (2008[a]), 'The Myth of Bryson and Economic Thought in Islam', Journal of King Abdulaziz University: Islamic Economics, Jeddah, (2008 C.E./1429 A.H.), 21 (1), 57-64.

Islahi, Abdul Azim (2008[b]), 'Thirty Years of Research on History of Islamic Economics: Assessment and Future Directions', in 'The 7th International Conference on Islamic Economics', Jeddah, Islamic Economics Research Center, pp. 347-69.

Islahi, Abdul Azim (2001), 'An Analytical Analysis of Al-Ghazali's Thought on Money and Interest', paper presented to the International Conference on Legacy of Al-Ghazali, organized by ISTAC, Kuala Lumpur, 24-27 October .

Islahi, Abdul Azim (1997), History of Economic Thought in Islam: A Bibliography, Jeddah: Scientific Publishing Centre, KAAU.

Islahi, Abdul Azim (1995), 'Islamic Distributive Scheme: A Concise Statement', in F.R. Faridi (ed.), The Principles of Islamic Economics and the State of Indian Economy, Aligarh: Indian Association For Islamic Economics, pp. 19-35.

Islahi, Abdul Azim (1988), Economic Concepts of Ibn Taimiyah, Leicester: The Islamic Foundation.

Islahi, Abdul Azim (1986), 'Ibn Taimiyah's Concept of Market Mechanism', Journal of Research in Islamic Economics, 2 (2), 55-66.

Islahi, Abdul Azim (1984), Economic Thought of Ibn al-Qayyim, Jeddah: International Center for Research in Islamic Economics.

Khan, Muhammad Akram (1989), Economic Teachings of Prophet Muhammad (pbuh), Islamabad: International Institute of Islamic Economics.

Knight, Frank H. (1955), 'Review article on The History of Economic Analysis, by Joseph A. Schumpeter', Southern Economic Journal, 21, 261-72.

Knowles, David (1963), The Evolution of Medieval Thought, London: Longmans.

Kramers, J.H. (1965), 'Geography and Commerce', in S. Thomas Arnold and Alfred Guillaume, The Legacy of Islam, London: Lowe and Brydone Ltd (from the first edn 1931 reprinted).

Krueger, H.C. (1961), 'Economic Aspects of Expansionary Europe', in Marshal Claggett, Gaines Post and Robert Reynolds (eds), Twelfth- 
Century Europe and Foundations of Modern Society, Madison: University of Wisconsin Press, pp. 59-76.

Kuran, Timur (1987), 'Continuity and Change in Islamic Economic Thought', in S. Todd Lowry (ed.), Pre-Classical Economic Thought, Boston: Kluwer Academic Publisher, pp.103-13.

Landreth, Harry and C. Colander David (2002), History of Economic Theory, Boston: Houghton Mifflin, 4th edn.

Lane-Poole, Stanley (1925), A History of Egypt in the Middle Ages, London: Methen and Co.

Langholm, Odd (1998), The Legacy of Scholasticism in Economic Thought, Cambridge: Cambridge University Press.

Langholm, Odd (1987), 'Scholastic Economics', in S. Todd Lowry, (ed.), Pre-Classical Economic Thought, Boston: Kluwer Academic Publishers, pp. 115-35.

Langholm, Odd (1979), Price and Value in the Aristotelian Tradition, New York: Columbia University Press.

Lewis, Bernard (1982), The Muslim Discovery of Europe, London: Weidenfeld and Nicolson

Lewis, Bernard (1970), 'Sources for the Economic History of the Middle East', in M.A. Cook (ed.), Studies in the Economic History of the Middle East, Oxford: Oxford University Press, pp. 78-92.

Lindberg, D.C. (1978), 'The Transmission of Greek and Arabic Learning to the West', in D.C. Lindberg (ed.), Science in the Middle Ages, Chicago and London: The University of Chicago Press, pp. 52-90.

Lipsey, Richard G. and Streiner, Peter O. (1981), Economics, New York: Harper International.

Lopez-Baralt, Luce (1994), 'The Legacy of Islam in Spanish Literature', in Salma Khadra Jayyusi (ed.), The Legacy of Muslim Spain, Leiden: E.J. Brill.

Lowry, S. Todd (ed.) (1992), Perspectives on the History of Economic Thought, Aldershot: Edward Elgar, Vol. 7.

Lowry, S. Todd (1987), Pre-Classical Economic Thought, Boston: Kluwer Academic Publisher.

Makdisi, George (2000),'The Reception of the Model of Islamic Scholastic Culture in the Christian West', in Ekmeleddin Ihsanoglu and Feza Gunergun (eds), Science in Islamic Civilisation, Istanbul: IRCICA.

al-Maqrizi, Muhammad Ali (1994), Ighathat al-Ummah, translated and edited by Adel Allouche as Mamluk Economics, Salt Lake City: University of Utah Press.

Mawdudi, S. Abul Ala (1963), 'Economic and Political Teachings of the Quran', in M.M. Sharif (ed.), A History of Muslim Philosophy, Karachi: Philosophical Congress, pp. 657-73. 
McChesney, R.D. (1976), 'Ad-Dimashqi', in J.R. Hayes (ed.), The Genius of Arab Civilization, Source of Renaissance, Oxford: Phaidon.

Meyerhof, M. (1931), 'Science and Medicine', in T. Arnold and A. Guillaume (eds), The Legacy of Islam, Oxford: Clarendon Press, 1st edn, pp. 311-55.

Menocal, Maria Rosa (1985), 'Pride and Prejudice in Medieval Studies: European and Oriental', Hispanic Review, 53, 61-78.

Metlitzki, D. (1977), The Matter of Araby in Medieval England, New Haven and London: Yale University Press.

Mirakhor, Abbas (1987), 'Muslim Scholars and the History of Economics: A Need for Consideration', American Journal of Islamic Social Sciences, 4 (2), 245-76.

Morison, Samuel E. (1963), Journals and other documents on the life and voyages of Christopher Columbus, New York: The Heritage Press.

Muir, S. William (1896), The Mameluke or Slave Dynasty of Egypt, London: Smith, Elder and Co.

Musgrave, R.A. and Musgrave, P.B. (1987), Public Finance in Theory and Practice, Singapore: McGraw-Hill.

Myers, Eugene A. (1964), Arabic Thought and the Western World, New York: Fredrick Ungar Publishing Company, Inc.

Nadvi, S. and Haq, Habibul (1976), 'al-Iqțā', in Contemporary Aspects of Economic Thinking in Islam, Takoma Park:American Trust Publications, pp. 93-119.

Newman, Philip, et al., (1954), Source Readings in Economic Thought, New York: W.W. Norton.

O’Brien, George (1920), An Essay on Medieval Economic Teaching, London: Longman, reprint 1967.

O'Leary, De Lacy (1968), Arabic Thought and its Place in History, London: Routledge and Kegan.

Olson, Mancur (1982), Rise and Decline of Nations, New Haven: Yale University Press.

Oser, Jacob and Blanchfield, William C. (1975), The Evolution of Economic Thought, New York: Harcourt Brace, 3rd edn.

Perlman, Mark (1977), 'Introduction', in Joseph A. Schumpeter, History of Economic Analysis, London: Routledge.

Pribram, Karl (1983), A History of Economic Reasoning, Baltimore and Lord: The Johns Hopkins University Press.

The Prince of Wales (1993), Islam and the West, Oxford: Oxford Centre for Islamic Studies.

Rescher, Nicolas (1966), Studies in Arabic Philosophy, Pittsburgh, PA: Pittsburgh University Press.

Rif'at, Syed Mubariz al-Din (1937), 'Ma'āshiyāt par Ibn Khaldun ke 
Khayālāt' (Ibn Khaldun's Views on Economics), Ma'ārif (Azamgarh, India), 40 (1), 16-28; 40 (2), 85-95.

Rima, Ingrid H. (2001), Development of Economic Analysis, London and New York: Routledge, 6th edn.

Rima, Ingrid H. (1991), Development of Economic Analysis, Homewood: Richard Irwin, 5th edn.

Rodinson, Maxime (1974), 'The Western Image and Western Studies of Islam', in J. Schacht, and C.E. Bosworth (eds), The Legacy of Islam, Oxford: Clarendon Press, 2nd edn.

Roll, Eric (1974), A History of Economic Thought, Homewood: Richard D. Irwin Inc.

Rosenthal, F. (1967)(trans), Muqaddimah of Ibn Khaldūn, (An Introduction to History) New York: Princeton University Press, Vols 1, 2 and 3.

Rosenthal, E.I. (1965), Averroes' Commentary on Plato's Republic, Cambridge: Cambridge University Press.

Samuelson, Paul (1976), Economics, New York: McGraw-Hill Inc., 10th edn.

Samuelson, Paul and Nordhaus, William D. (2001), Economics, New York: McGraw-Hill, 17th edn.

Samuelson, Paul and Nordhaus, William D. (1985), Economics, Singapore: McGraw-Hill Inc., 12th edn.

Sanchez, Expiracion Garcia (1994), 'Agriculture in Muslim Spain', in Salma Khadra Jayyusi (ed.) (1994), The Legacy of Muslim Spain, Leiden: E.J. Brill, pp.987-99.

Sarton, G. (1924-1948), Introduction to the History of Science, Washington: The Carnegie Institute of Washington, Vols 1, 2 and 3.

Sauvaget, J. (1965), Introduction to the History of the Muslim East: A Bibliographic Guide, Berkeley: University of California Press, 2nd edn.

Schumpeter, Joseph A. (1997), History of Economic Analysis, London: Routledge.

Scott, William R. (1949), 'Greek Influence on Adam Smith', in Études déchié es a la Memoire D’Andre’ M. Andréaèds, Athens: Prysos.

Semaan, K.I. (ed.) (1980), Islam and the Medieval West, Albany: State University of New York Press.

Sharif, M.M. (1966), A History of Muslim Philosophy, Weisbaden: Otto Harrassowitz, Vols 1 and 2.

Shemesh, A. Ben (1969) (trans.), 'Taxation in Islam' (Vol. III), in Abu Yūsuf, Kitāb al-Kharāj, Leiden: E.J. Brill and London: Luzac \& Co.

Shemesh, A. Ben (1967) (trans.), 'Taxation in Islam' (Vol. I), in Yahya ben Adam, Kitāb al-Kharāj, Leiden: E.J. Brill (rev. edn).

Siddiqi, Muhammad Nejatullah (2008), 'Obstacles of Research in Islamic 
Economics', in 'The 7th International Conference in Islamic Economics', Jeddah: King Abdulaziz University, pp. 3-12.

Siddiqi, Muhammad Nejatullah (1992), 'Islamic Economic Thought: Foundation, Evolution and Needed Direction', in Sadeq and Ghazali (eds), Readings in Islamic Economic Thought, Selangor: Longman Malaysia, pp. 14-32.

Siddiqi, Muhammad Nejatullah (1982), Recent Works on History of Economic Thought in Islam - A Survey, Jeddah: International Center for Research in Islamic Economics.

Siddiqi, Muhammad Nejatullah (1980), Muslim Economic Thinking, Jeddah: International Center for Research in Islamic Economics and Leicester, Islamic Foundation

Siddiqi, Muhammad Nejatullah (1964), 'Abū Yūsuf Kā Ma'āshi Fikr' (Economic Thought of Abu Yusuf), Fikr-o-Nazar, 5 (1), 66-95.

Smith, Adam (1937), An Inquiry into the Nature and Causes of the Wealth of Nations, New York: The Modern Library.

Smith, Margaret (1944), Al-Ghazali the Mystic, London: Luzac and Co.

Smith, R.B. (1876), Mohammed and Mohammedanism, London: Smith Elder.

Spengler, Joseph J. (1964), 'Economic Thought of Islam: Ibn Khaldun', Comparative Studies in Society and History (The Hague), 6, 268-306.

Spengler, Joseph J. (1971), 'Alberuni: Eleventh-Century Iranian Malthusian', History of Political Economy, 3 (1), 92-102.

Tawney, R.H. (1938), Religion and the Rise of Capitalism, London: Penguin Books.

al-Tunisi, Khayr al-Din (1967), The Surest Path (English translation of Aqwam al-Masālik fì Márifat Ahwāl al-Mamālik by Leon Carl Brown, under the title The Surest Path), Cambridge: Harvard University Press. al-Tusi, Nizam al-Mulk (1978), Siyāsat Nāmah, translated by Hubert Darke, London and Boston: Routledge and Kegan Paul.

Viner, Jacob (1978), Religious Thought and Economic Society, Durham: Duke University Press.

Watt, Montgomery, W. (1972), The Influence of Islam on Medieval Europe, Edinburgh: Edinburgh University Press.

Whittaker, Edmund (1960), Schools and Streams of Economic Thought, London: John Murray.

Wonnacott, P. and Wonnacott, R. (1986), Economics, Singapore: Mc-Graw Hill, 3rd edn. 